\title{
DIASPORA AND FORMATION PROCESS OF INDONESIANESS: INTRODUCTION TO DISCUSSION
}

\author{
Singgih Tri Sulistiyono ${ }^{1}$
}

\begin{abstract}
This Working Paper is actually a wide research plan of its effort to review Indonesianess spirit which is lately facing a hard test and challenge. The odd thing is the threat to Indonesianess continue to occur when the age of NKRI (Negara Kesatuan Republik Indonesia) becomes older and older (currently, the age is 66 years old) and the macro economy is developed more (included in G20 Countries), the world respects formal existence of any country, human rights, the information technology development becomes more sophisticated.

There are sufficient reasons to prepare indications that the glue for Indonesianess becomes more fragile and experiences deterotiation process. The question may arise: awhat is the glue and adhesive material for Indonesian people and what is the function of the flue and adhesive material in formation and development process of Indonesian nation? This glue and adhesive material arevery important because Indonesian nation is formed by various and different ethnic, social, religion, race which in pre-Indonesian era, they became the cause of any serious conflict. Moreover, in many cases, raceand ethnic becometheglue in formation process of nation. In relation to thequestion concerning theglueand adhesive material in Indonesian nation formation process, leaders of the first national movement quoted Ernest Renan opinion that the collective wish and hope (in order to become a nation) will become the glue and adhesive material of the nation itself. He said that a nation is a soul, a spiritual principle.
\end{abstract}

Key words: Diaspora, Indonesianess Spirit, NKRI, Colonialism, separatism, national movement

\section{Introduction}

At the beginning of $\mathrm{XX}$, for example, there were a commitmen between the national movement roles studying in Nederland that the independence of Indonesia was the nation of all native people in Hindia. The difference of ethnic

1 Prof. Dr. Singgih Tri Sulistiyono, Lecturer of History major, Cultural Knowledge faculty, Dipenogoro University, Head of Indonesian Historian Community, Central Java Branch. This Article has been reviewed by Prof. Helius Sjamsuddin, M.A (Indonesia University of Education), Prof.Dr. Rochiati Wiriaatmadja, M.A (Indonesia University of Education), and Prof. Dr. Hansiswany Kamarga, M.Pd ((Indonesia University of Education). 
should not make an obstruction of Indonesian identity development (van Miert, 2004: 30). Otherwise, in the event that hope and commitment are faded or lost, and thereforeThe glue and adhesive material will also fade and lost. There is also an argumentation that the occurrence of collective wish and hope are born from fate similarity as Dutch colony (Soekarno, 1965: 32-33). The same fate as colony will create a collective wish to be free from colonialism and build a life as a justice and wealthy nation as always be said by Bung karno: "our goal is people prosperity" (Mangunsumbogo, 1958: 27). It is also written in the Preamble of 1945 Constitution.

Meanwhile, Drake stated that there are some factors becoming catalisator or glue for Indonesian nation integration namely: history writings as collective memory, collective cultural symbol, equalization in economy development and relation between countries. The four catalisator elements have influence and synergy one another. However, the incidents for the last decades show that history internalization as collective memory and collective symbols creation is not obstructing the wish of some areas to separate from NKRI. And therefore, there are only two others catalisator factors namely equalization in economy development and relation between areas. Economy development equalization factor (Spatial and vertical) is really important and significant in strengthening nation integration. The non equalization in economy development often becomes the reason for any area having natural resources potency to separate from NKRI government. However, it is mainly related to any period when the nation countries have been formed and established.

Furthermore, relation between areas is also important and significant in the countries formation established and formed from various ethnic groups. In this case, inter cultural communication becomes the significant factor in Indonesian nation formation process including Indonesianess formation. In relation with the inter-cultural communication in Indonesian history, diaspora role is very significant. Therefore, this research tries to review the diaspora phenomenon within Indonesianess formation and enhancement context.

\section{Indonesianess Spirit is in trouble?}

The main objective of this research is to provide certain perspective on understanding Indonesianess concept by historical narration and explanation. This explanation is necessary for various Indonesian community recently as a result that this Country obtains double pressure both from globalization and localization wave. Until now, Indonesianess perspective is often comprehended differently among various social and ethnic group and among the leaders and community as well as among the Central Government and regionals. It is possible that sometimes the differences can become the conflict root and even bloodshed (Drake, 1981: 471-472). Certainly, The aim and objective of this research is not for indoctrinating the Indonesianess perspective. The result of this research is projected to take part in the effort of giving enlightment that Indonesian nation, 
country and people is actually a result of long history process involving various social elements in Indonesian archipelago (Frank, 1998: 97-98). One of the historical strength to support the history process of Indonesianess establishmentis diaspora phenomenon enabling the occurrence of cross-cultural communications among cultural social elements which will become the part of Indonesian nation community. The cross cultural relation can be in form of dialogue, competition, conflict, accommodation, acculturation, assimilation, etc which always find the new equalization forms within social, cultural and politics relations (Sulistiyono, 2008). Process to be Indonesia is actually a result of dialogue within history process and also dialogue with history, even, according to Ben Anderson, the Indonesian concept is the new concept found in XX century (Anderson, 1983: 19).

Eventhough Indonesiahas been established formorethan six decadessincethe proclamation of Independence on August 17th 1945, the formation of Indonesian nation and community continues to be in the process. Meaning that "process to be Indonesia" within socio-cultural context is continued on progress and difficult to be predicted when it will be completed and finished. Ben Anderson formulates Indonesian community and nation formation process with interesting concept namely imagined community and also imagined nation (Anderson, 1983: 224). It means that Indonesian community and nation is a nation and community imagined or aimed to be different with the community and nation in the reality. Certainly, a goal will require a process to be achieved. Achievement of goal and objective will give two possibilities: succeed or failed. In theevent that it is succeed, and therefore synchronization between Republic of Indonesia (RI) as container, and community or nation as the content will be existed. Otherwise, in the event that the process is failed, and therefore the process of Indonesian community and nation establishment will not in line with the establishment of the country of the Republic of Indonesia which at the end, it will cause the collapse of the country of Republic of Indonesia or the country of Republic of Indonesia is not same as the country established in the year 1945, for example, in case that Papua, Aceh, Kalimantan separate themselves from the Republic of Indonesia.

Process to beIndonesian community and nation will have strong relation with the growth and development of Indonesianess spirit or the spirit to become the inherent part of Indonesian nation and also sense of belonging in every member of Indonesian nation community. The sense of belonging (J avanese handarbeni) is related to the loving sense ( $\mathrm{J}$ avanese hanresnani) and willingness to maintain it (J avanese: hangrungkebi) from any and all challenges deemed as destructive that will destroy it. The occurrence of separation movement from the country of the Republic of Indonesia, whatever the reasons are, may become a reflection of how 'sense of Indonesianess' remains to be the serious issue.

The issue until the recent days is that phenomenon of regional resistance and separatism movement phenomenon in various region often see from the central perspective, in this case the Government of the Republic of Indonesia in J akarta. Every form of resistance and separatism is considered as disloyalty behavior manifestation and denial to noble consesus from the founding fathers 
who have initiated the establishment of the country of the Republic of Indonesia. Authority logic of Central Government is based on the premises that extinguishing of regional resistance and separatism is a mission to enforce noble consensus enforcing the country of the Republic of Indonesia. And therefore, every repressive action of Central Government obtains justification of the premises having the same thought and consideration. Performing and implementing repression, it is almost unheard that the central Government performs introspection to answer the question concerning why resistenace and separatism movement occur.

It is so interesting to see local and national persepective as well as regional and central government contradiction related to the issue how the country of the Republic of Indonesia is maintained. Central Government is likely to always consider that the consensus process leading to the proclamation of independence of 17 August, 1945 is the final consesus which is the fixed price to be maintained. Recently, MPR is intenselt socializing the four pillars of state and governance namely Pancasila, Constitution of 1945 (also known asUUD 1945), Bhinneka Tunggal Ika, and NKRI. Even, the Head of MPR RI, Taufik Keimas, wishes to form special institution or entity to socialize the four pillars of state and governance. The discourse of NKRI, Pancasila, and Constitution of 1945 (Also known as UUD 1945) is the final consensus which actually has been announced with the President Nominees in General Election for President, year 2009. The three President Nominee, Megawati Sukarnoputri, Susilo Bambang Yudhoyono, and J usuf Kalla, explained in the debate of President Nominee that NKRI is the final consensus and fixed price. A couple days after the memorial of Pancasila, the ex president, Megawati, said that the four nation pillars which are Pancasila, Constitution of 1945 (Also known as UUD 1945), Bhinneka Tunggal Ika, and NKRI, must be revitalizated immediately. This is delivered when she sees the slow motion of the Government in handling NII (Indonesian Islamic State) case.

The discourse that NKRI as final consensus and fixed price is believed as a result of the sense and spirit having the same fate as the colony and wish for an independent, united, sovereigned, justice and prosper Country as entered into Constitution of 1945. It can be imagined that the country to bebuilt and developed at that time is the country capable and willing to protect its nation and create public prosperity as well as educating the nation. It has became social contract (Chang, 2010). Often, the repressive action of the Government are only based on the part of the spirit namely surviving to the end toward the 1945 consesus, without seeing whether the country function has been run in accordance with the consensus and goal. However, based on the regional perspective, the function and benefit of the country of the Republic of Indonesia is more important and significant than the agreement itself.

And even some question often arise, what is the benefit joining Indonesia if we are exploited and poor? Is it better to stand alone and joining other country having more prosperity and justice? And therefore, it must be the time for Central Government to implement prosperity and justice approach more than repressive approach both political or military. This concern and awareness must benecessary to be built and developed by historical narration concerning Indonesianess. This 
concern and awareness is actually the part of consensus and noble goal in theyear 1945.

The changes occur within the community which is not completely catched by the Government elites is that the indonesianess and nationalism can no longer solely develop and build by historical romance, for example, stating that we are the nation having the same fate as colony as often voiced by nationalist roles including Sukarno (Anderson, 1983: 224). It is the fact that generally colonialism phenomenin is experienced by any and all Indonesian nation element even at taime, not any and all social groups in Indonesian island feels to be a colony. The colonial Government was intentionally created partial law system based on racial and status line. Based on the method, they tried to create colonial community with apartheid spirit. Written in article 109 of Government Regulation (Regeering Reglement) year 1854, for example, it was stipulated that there was a community level or group differentiation : European group and people equalized with European at one side, and Native peopleat the other side. At the beginning, Native People category also covers the immigrant from Asia including Chinese, Indian, Arab, etc. However, they were separated into two groups with Foreign East group having the second position after European Group. And therefore, the ethnic and race criteria become the basis of law structure of colonial community (Houben, 2002: 61). And therefore, at that time, Indonesian community was facing the structural injustice which was intentionally created by collonial authority placing native people at the lowest position in collonial community structure. Culturally, this policy has made Native people suffered from minderwardigheidscomplex, it is a chronic inferiority syndrome. The people having high benefit descent and status by Colloinialism system would not feel as colony and even feel as the colonist. Collonialism has created the antagonistic community basis. Actually, not all Indonesian people elements experienced as a colony at that time.

In this case, it will be necessary to be recorded that the same fate feeling as the nation colony is contextual. Perhaps, in the mean time, especially before war generation, the Indonesianess spirit could be built by historical romance. However, now, when the era has changed, generation has changed, the historical romance can no longer be used to preserve indonesianess spirit. Many practice aspects becoming important and significant consideration which is how the country of the Republic of Indonesia had ever been treated as noble consensus defended together is capable to give prosperity, wealth, justice and proud to every citizen. The wish is a natural thing.

As a nation experiencing the bitter od long colonialism, they imagine that the Indonesian country replacing colonial country will be capable to give economical prosperity, political independence, and dignity as well as cultural pride as announced by Bung Karno. Socialistic hopes concerning the new country to be established colors the idea of the founding fathers when they prepare the establishment of the Republic of Indonesia (Sulistiyono, 2008).

Other actual problematics inidicated for the recent decade is the development of regional sentiment, regional son issue, ethnicity, religion conflict. All of them are antecendent for Indonesianess formation process. During this reformation 
period, conflict case numbers are uncountable starting from social group and ethnic as well as religion conflict to the ethnic chartasis indication (Elson, 2009:. 433-434). Certainly, deductively, peoplecanbealleged that thesocial phenomenon will be difficult to be achieved in the event that the justice, prosperity and welfare can be experienced by Indonesian people and also indonesianess spirit owned by any and all Indonesian people elements.

Therefore, it can be underlined that some crucial and actual issues faced by Indonesian people including that the establishment of the country of the Republic of Indonesia in the year 1945 as formal politics association has not been completely followed by formation process to be a community and Indonesian people and therefore indonesianess spirit remains to be an issue. Various incidents in form of inter-ethnic conflicts, resistance and separatism movement showed that indonesianess spirit (in the event that it has been occurred) in some situations and/or for certain interests remain to be sacrificed for the purpose of ethnic interest, locality, primodialism and other interests. In addition, along the Indonesian history, the approaches implemented by Central Government tohandle and settle socio-cultural and national disintegration was focused to security and politic approaches. Security and repression approaches will cause nation disintegration in its politics and dis-indonesianess in its social and culture. In this case, the Government must focus more to prosperity and justice approaches in handling and settling disintegration conflict and threat as well as dis-indonesianess indication. .

Therefore, politic and military approaches as well as indoctrination in internalizing indonesianess spirit must be necessary to be replaced by sociocultural approaches. In this case, nationalism history study in schools and other formal educational institutions must be very important. The issue is what type of history study material effectively able to grow and develop indonesianes spirit for the students because until now, the students has received history lesson as their subject in schools. Generally, history study material for developing indonesianess spirit is the material describing 'process to be Indonesia', a long process and an inevitably historical process requiring various social and ethnic groups to be Indonesian nation not other nation.

And therefore, "process to be Indonesia" is not a new thing started from national movement era, moreover, it is started from 17 August, 1945. Narration and explanation concerning "process to be Indonesia" is necessary to be started as of ancient era to the recent era. Decolonization of 17 August, 1945 was only one of the most important pillar in the 'process to be Indonesia' which is the establishment of the country of the Republic of Indonesia. The event was only one point of evolutionary process from a process called "a process to be Indonesian" (as community and nation). It is undeniable that colonialism has thick color in "process to be Indonesia" especially when theWest Colonialist plotted the physical and politics borders, people to be included in Netherlands Indies community (it would become Indonesian citizens), people to be included in British Malaysian community (it would become Malaysian citizens), etc (Ricklefs, 1981: 138 and 
Henley, 1996: 5). However, once again, the proclamation of independency was only a little part of long-term evolotionary process of being Indonesia.

And therefore, indonesianess formation process is not only started from the year 1945 and not XX century, but it has been started before the era and even the indonesianess development and growth by history must be necessary to be presented by the long historical description and explanation

\section{Conceptual Framework : Diaspora and Formation of Indonesianess}

The main theme becoming analysis unit in this research is the historical indication called as diaspora related to indonesianess formation. In this case, the Indonesian concept covers the way of thinking, sense and act from the people coming from various regions, ethnic groups, socio-cultural and economy background in Indonesia but having the same feeling and sense as the part of community and nation called Indonesia. In such context, history experience actually roled as common experience is the important factor in theindonesianess formation process. The shared experience as a community both in its glorious and destruction era, winning and lost era, struggling and success era will grow the sharing feeling and sense in the life as nation community (Drake, 1989: 16).

In this case, diaspora phenomenon in archipelago is the history power giving contribution to indonesianess formarion process in this modern era. It is in accordance with the statement of Gilroy: "modernity is inevitably a transcultural, international, diasporic, and hybrid formation" (Gilroy, 1993: 127). In Indonesia, study of diaspora is not much implemented, but in international level, as of the past one decade, diaspora phenomenon is a trending topic obtaining many attentions especially from historians, sociologists and experts in other field studies. Diaspora or diaspora flow is a process where a number of people immigrating and staying in other region or country. The definition of diaspora concept is approximately sameas migration concept. However, migration concept is a wider concept referring to the human movement from one place to another for the purpose of staying both permanently or temporarily.

Diaspora are coming from noun in Greek "diaspora" which becoming 'dispersion' in English having disperselexical meaning or spreading. Theverbform of diaspora work is 'diaspeiro', meaning dispersing overseas or domestic (Arakaki, 2002: 26). Recently, the social scientist uses the term of „diaspora referring to the migrants living in overseas regions and creates the new generations in overseas whose maintaining family relationship and regularly visiting one another and their origin regions. In the world history, there are some big diaspora including $\mathrm{J}$ ewish from Palestine as a result of politics upheaval and war, Negro from Africa as a result of slavery, Irish, Armenian, Indian, etc. In this case, diaspora can have small scale including Palestin diaspora in various Arabian countries (Manning, 2003: 2). Likewise, the diaspora phenomenon has been implemented by human group as of ancient era. Austronesian people diaspora as one of the Indonesian 
nation ancestors has been implemented from Asian land to the archipelago as of 4000 BC (Vlekke, 2008: 7-12).

In this ghlobalization era, human, goods, service and information movement penetrating the space borders has reduced and decreased the gap between one place with another place and created the establishment and spreading of diaspora community. In the world history, diaspora discourse often creates unpleasant experiences including the experience of a person trapped between foreign culture, the difference between reality and imagination, bitter experience to adapt with local community culture after moving from one place to another place having differences of race, culture, language, etc as isolated people, slave, refugee, asylum seakers, migrant workers, politic victims, sellers, military conquest, etc. Likewise, the newcomer often faced the issue of inferior status, castrated political rights, etc. The issues are also occurred in Indonesia for years between the native and non native, regional son and non regional son, etc.

According to Manning that the terminology of "diaspora" coming from Greek at that time was actually exclusively used for describing the spread of J ewish people all around the world. As we know that after the expansion of Babylon Kingdom, most of J ewish people living in Palestin was transported and occupied as slaves in this Kingdom. After the lost of Babylon Kingdom, they spreaded to various directions of Middle Sea including Greek. However, in the modern study, this concept was previously a concept to study the spread of millions of African people all around the world as a result of slavery. The study is started as of the middle of 1960s initiated by George Shepperson and J oseph E. Harris. And then, it developed as various studies for the spread of various nations in the world ((Manning, 2003: 2).

East Asia and Southeast Asia areas was not slipped from diaspora study. Eventhough, at the beginning the study toward Chinese peple across the country was not using diaspora concept, based on substantial side, it also studied one of diaspora aspects which is the life outside their area including the work of Victor Purcell (1951), Fitsgerald (1965), Wang Gungwu (1978), etc. In addition to the Chinese people, various research concerning diaspora is also implemented to various groups of nomads in Southeast Asia including Arabian, Indian, Bangladesh, Tamil, etc.

Meanwhile, the diapsora study as the historical phenomenon has not been much implemented to various social and ethnic group in Indonesia islands. The pioneer work in form of article concerning diaspora of Bugis-Makassar people in Indonesian island is written by Leonard Y. Andaya as an article in the year 1995. He said that the efforts performed by European people to dominate economy life in Southeast Asia during the first modern period causes disturbance in community living especially for the islands of Southeast Asia. He said that one of the most spectacular examples in this case is diaspora of Bugis-Makassar from South Sulawesi. For two centuries, they spreaded to Sumbawa, Lombok, Bali, J ava, Sumatera, Malay peninsula, and West Kalimantan. Makassar peopleis the most strong dispora group with the thousands exodus lead by the ex-official of the Kingdom after Makassar Kingdom and authorized by VOC (Nagtegaal, 1996: 
21). Eventhough, at the beginning they are warmly welcomed, the status of the leaders and their number becoming bigger and bigger create an issue in the new place. Their failure to well stay overseas causes the group of Makassar people becoming big hreat for VOC hope toward the stability of Indonesian archipleago. This is one of the reasons why Dutch people implemented military expedition to Makassar in the year 1667. Meanwhile, Bugis diaspora achieved more success. Their success is caused by historical situation and uniqueness of Bugis people to perform modernity. They became the well-stayed group at Malay world and east side of SUmatera beach (Andaya, 1984: 159-167).

The second pioneer work written by Cummings concerning diaspora of Malay people in Makassar for the XVI and XVII Centuries. He said and explained that annexation of Mallaca by Portugese in the year 1511 causes Malay diaspora in all Indonesian archipelago. Malay people seeked for the new living place by bringin the developed culture and Islam.Malay people often became the close partner by marriage with the local authority family. He gave description and illustration from Malay community history in Makassar and the relation with the authorities and Gowa Government in Makassar. In this overseas area, Malay people were also involved in the conflict between Gowa and VOC, even both of them remained to have no clear borders (Cummings, 1998: 107-122).

It is necessary to be mentioned that the effort to study diaspora in the archipelago is also perfomed by Muchlis Paeni. In his short popular writings, he tried to relate dispora Bugis-Makassar phenomenin with national revival. One thing becoming very interesting is that the diaspora

Phenomen has been proven as the media of cross- cultural communication amongvariousethnicgroupin Archipelago. Theresult of thiscrosscultural relation is the establishment of understanding one another and also the establishment of the superior indonesianess identity. In this relation, Paeni found the interesting phenomenon that dr. Wahidin Sudiro Hoesodo becoming the national revival role model becoming crossbreed between Makassar and J ava. As you know that as of the XVII century, MAkassar people performed diaspora to Mataram under the authority of Karaeng Galesung. Dr. Wahidin is the diaspora descent educated within J avanese culture environment (2008, 2008: 44-45). Many roles from the newcomer ethnic group capable to build togetherness with local ethnic including the story of Islam spread from Minangkabau namely DatukRi Bandang spreading Islam in the area of Sulawesi and Maluku. Likewise, the J avanese traditional story concerning Fatahillah coming from Aceh in the Demak Kingdom area. It is possible because the trading and shipping developed in Archipelago before the coming of West nations (van Leur, 1983).

And therefore, the historical study concerning diaspora phenomenon in Indonesia has not optimally developed. Considering historical and geographical factors, Indonesian Islands should become the land of diaspora' even based on the scale, it is not big as diaspora of African and J ewsih people. Likewise, the diaspora occurs in Indonesian Islands area is not only the inter-country diaspora but also considered as internal diaspora within Indonesian archipelago and its surroundings. However, theinternal diasporahistorical phenomenonisinteresting 
to be studied related to the process of growth of Indonesianess spirit within the Archipelago. This study is very interesting in line with the development of the use of diaspora use which is no longer mainly related to the politic upheaval and war as occurred in the J ewish community and also slavery as occurred in African people, but diaspora concept has been developed as the new and challenging concept.

In line with the human mobility wave becoming higher and higher in glovbalization process. Following knowledge, transportation technology and communication development becoming more sophisticated, the current social science and cultural study are challenged to develop the way of thinking and assumption to reveal that it is not only the inter-cultural community or mullticultural community, contemporarily, but also their past related to authority reation, rural communities and borders, concerning the spread of culture, communication and translation/interpretation, riot and revolution, etc. The various issues related to diaspora require re-explanation of social knowledge theories including the explanation of historical study. It will open the historical studies within new perspective concerning the issues which are actually popular including migration wave, identity establishment, overseas community including their mentality structure, nationalism, colonialism, neo-colonialism, gender, manpower, etc (Fabre \& Klaus Benesch, 2006).

This research will focus to the relation between the diaspora phenomenon occurring in Indonesian archipelago with the growth of Indonesianess identity As previously stated that historically and geographically the Indonesian archipelago can be referred to as the land of Diaspora', the country of Diaspora. Diaspora is an inherent part in the history of Indonesia. Diaspora of social, ethnic, and racial history are coloring Indonesian history. Some of them may be mentioned are: Aceh, Malay, Batak, J avanese, Madurese, Banjar, Bugis, Makassar, Buton, Bali, Ambon, Papua, Chinese, Arabic, India, Netherlands, etc (Abushouk, 2009). Netherlands, etc. This phenomenon has made Indonesia a multiethnic society (Brown, 1993: 43-60). In thisstudy, theDiasporaisnotonly seen asaphenomenon of population displacement (or commonly called the concept of migration), but also issues related mainly to cross-cultural relations with all its complexity as the network business (shipping and trading), power relations and politics (including competition , conflicts, wars, etc. as well as the nationalist movement since the twentieth century), the formation and transformation of identity, media relations and various cross-cultural education, political party, mixed marriages, and so on. Given the broad scope of the research is necessary to review the case study examples from the Diaspora of the J avanese, Bugis-Makassar, Madurese, Batak, Bali, Papua, Banjar, Ambon, Buton, and some similar.

Diaspora studies in the Indonesian archipelago might be enlightening to the process of identity formation of Indonesia's. It is closely related to the historical fact that the Diaspora is one of the strong currents in the history of Indonesia. In relation to the position of the Indonesian archipelago as the land of Diaspora', the so-called "indigenous" or "native", which is often the root causes of ethnic conflict, racial, and provincialism need to be revisited. 
In the context of the history of the Diaspora in the archipelago, there may not be the natives of the archipelago. If there is a genuine archipelago, various types of early humans may be the oldest inhabited archipelago. Even based on the research, they also are not "original" Nusantara, but came from mainland Asia or Africa. The same is true of the various tribes in the islands that are all immigrants from mainland Asia. Perhaps the question is who comes first. As it is known that the Diaspora of Austronesia and Papuan-Melanesian archipelago came into the waves. According to Robert Cribb, Austronesia. Diaspora that reaches over half a circle of the earth is man's most spectacular migrations in the world of pre-modern era (Cribb, 2008: 30). It is possible that even though they still have a cognate relationship, because the separation of time and place far not possible conflicts between the old settlers and newcomers. This not only happens among Austronesia descent but also among the Melanesian people of Papua in Papua. But all of that is actually part of the social process in history to produce accommodation, acculturation, or assimilation that produces a new balance in life together as a community. Likewise the internal Diaspora in the archipelago between one island to another, from one region to another place in the history of Indonesia that has created a dynamic equilibrium and as well as new adaptations and the process of formation and transformation of identity as a community. The emergence of Indonesia's identity since the early twentieth century was also a part of the dynamic processes in the context of the internal Diaspora for under the authority of the Dutch colonial government. In this case, the phenomenon of Diaspora not only produce fruit community compartmentalized box like a mosaic, but also produces a more fluid society hybrids Indonesia's identity as far as Indonesia's identity can be maintained. If not maintained properly then that will happen is the formation and reshaping a new identity that might not be in line with the imaginable identity of the Indonesians (Khattab, 2010:162).

The arrival of Dutch and other Europeans to the islands from one side is also a maritime Diaspora phenomenon. Actually, Nusantara peoplefamiliar and interact socially with newcomers like the people of India since the early centuries, the Arabs and Persians since the spread of Islam. One of the things that distinguish between those with previous Western Diaspora with other Diaspora is that the West is not only a trade or settle in new areas but colonization. They impose a monopoly, loot, occupy, and exploit, and suck the area to be sent to the country. So they brought a new model equipped Diaspora with the tools of violence in both systems of military technology and social technology. Diaspora model of colonization which is a product of modern capitalism in Europe at that time have created a clear separation between the colonizer with colonized. Perhaps the term "indigenous people of Indonesia" may come from a concept developed by the Dutch colonial government which is the concept of "inlanders" to separate them clearly with "Holanders" or "Europeanen" in general. As for the situation fully vragilitas meciptakan in society, the Dutch colonial government created the concept Vreemde Oosterlingen (officers) in which, among others China, India, Arab, and so on. Actually, before the Dutch came, what was then called the officers already Diaspora in the archipelago since hundreds or even thousands 
of years before the Dutch came. They have built social relations that generate the process of accommodation and acculturation as can be seen in world trade, political systems, the spread of religion, identity transformation, and cultural materials such as building temples, mosques, monasteries, temples and so on. Chinese Diaspora, for example, has a significant contribution in the establishment of Muslim community archipelago at that time (Graaf, 2004: 14-17). Perhaps the legacy of the phrase "Chinese people" which contains specific connotations and contain expressions of hatred born of Dutch colonialism when they placed a particular part of the machinery of colonial exploitation.

Social fragility can also be created or strengthened in the "inlanders" itself. Despite the mutual respect for various ethnic groups in the Netherlands Indies are categorized in the "inlanders" but due to the plurality of existing conditions, the colonial government tried to dividing them by creating strict boundaries between ethnic groups with each other, among others, can be seen from the residential segregation in cities controlled by the Dutch colonial government Belanda (Widodo, 2004). Also create administrative boundaries based on ethnicity and then Dutch call a "plaatselijke bevolking" (locals). This concept is reasonably suspected to have metamorphose become" sons of area "which sharpens the term primordial lines and provincialism in Indonesian society today. The dichotomy between J ava and outside J ava in the post-independence is often a political issue for the resistance and perhaps also a legacy of separatism that is administratively divided the colonial Dutch East Indies in thelineinto two, namely J ava \&Madoera and Buiten Gewesten (Buiten Bezittingen). Fragility is also conditioned by formation of the army based on ethnicity. Resistance in a region will be turned off by soldiers from other ethnic groups so that inter-ethnic sentiment and antipathy with the unconditioned (Veer, 1977: 205-210).

Whatever thepolicy adopted by thecolonial government, theinternal Diaspora among social and ethnic groups in the Netherlands Indies continued. In this case the cities are well developed as the central government as well as economic and trade centers as well as education became the center of the Diaspora. It has become one of the factors that allow social relations between different racial groups, ethnic and status which in turn contributes to the feeling of a particular cause of mutual understanding and the establishment of Indonesia's spirit. The process continues until the post-independence period and even now with the rhythm of ups and downs from time to time.

\section{Research Substance}

This research includes spatial and temporal scope is quite long and therefore be broadly divided into two main sections. The first part will examine the history of Diaspora and migration that occurred in the Indonesian archipelago, both the Diaspora by other external countries such as India, China, Arabs, etc., as well as the internal Diaspora committed by various ethnic groups in the Indonesian archipelago. Discussion of the history of the Diaspora in the archipelago covers 
a long period since the initial period until today. Long period it can be divided into several periods, ie; periods old archipelago (up to the fifth century), Hindu and Buddhist kingdoms period (VI-XV century), the period of the Islamic empire (XV-XVII centuries), the period of colonial domination (XVII-XIX century), the National Awakening period (XX century), and the period of independence.

In the initial period will be described in a series of Diaspora by the ancestors of Indonesia both Austronesia and Papuan Melanesian. In the essence that they are not genuine citizen of the archipelago. They are all immigrants. Because it comes in waves for periods ranging from one thousand years of Diaspora waves with other waves and form a distinct ethnic group. Separation distance and time between waves of the Diaspora has been blamed for the growth of hundreds of ethnic groups in the archipelago. The group that first came to claim the territory they occupy as their right. However, in principle they are all immigrants, not natives of the archipelago. Of course, conflicts can occur and the newcomers who usually bring new technologies into previously urged the group to the interior.

Entering the first century, the people who inhabit the archipelago is not only depends on subsistence economy. They become involved with international trade between China and India throughout the archipelago. The ability of exploring the ocean becomes an important capital in trade activities. However, shipping and commerce not only the media to build relationships with India and China, but also the media do the relationships among the various tribes that inhabit the archipelago. Shipping and trade networks not only involve people who live on the coast of the archipelago, but also a variety of ethnic groups that exist in the inner part especially those who live in the river valley region (Hall, 1985). In line with the development of maritime trade, it makes also the influence of Hinduism and Buddhism are not only limited to the beaches, but also rural communities. Some of the political center of the archipelago, and then take advantage of economic development and new religions to build greater political strength to master the potential of developing economies. Thus, migrants who are geographically separated to gain momentum to make contact and communication through trade, spread of religion, and politics. Through thesechannelsisalso an internal Diaspora in the archipelago also occur so that the process of cross-cultural communication and re-familiar with the process of happening.

During the spread of Islam, the process continues. Although in many places the general strength of Hinduism and Buddhism were replaced by Islam, crosscultural relations between ethnic groups and social groups in the archipelago continues to walk through a tradingnetwork, with all forms of political interaction, maritime Diaspora, and so on. Even the expansion of the marine community not only covers the western part of the archipelago, and East to the Moluccas and Papua (Widjojo, 2009). While uhabistyh bends, communities in the archipelago hasmore political experienceas a community, bothin timeof Mataram, Majapahit, Sriwijaya, Demak, Aceh, Makassar, Bali and so really, at some stage, it is not only an ethno-State of the State, but crossed the boundaries of ethnicity ethno supra ethno-state polity. 
In the next period when Western countries began arriving in the archipelago, the spread of religion, Diaspora, maritime, and politics relationships still ongoing. Even the arrival of the VOC monopoly and push some particular ethnic Diaspora to perform a wider area so that the process of cross-cultural relations between ethnic groups in the vast archipelago as well. Port cities and trade at that time became the arena of cross-cultural communication for the plural society. Various forms of social relations in the form of competition, conflict, and accommodation occurs both internally among the various tribes and external forces with Dutch and other foreign troops.

The establishment of the Dutch colonial government to providemore in-depth experience to social and ethnic groups together to become the subject of a great colonial state. If the social and political conflicts of the past are still marred by conflicts of interest, both among ethnic groups and among certain ethnic groups in the Netherlands, but in this period seems to conflict between communities began islands cone (consisting of various ethnic groups) with the Netherlands as representation of the colonial government. This is in line with the weakening and even destruction of local political power. Shared experience as a colonial society this is the beginning of the twentieth century is often used as campaign material to evoke the spirit of nationalism by leaders of national movements. This was despite the fact that not all social groups to feel depressed because there are certain groups that are still part of the machinery of colonial exploitation. The problem has become one of the factors of division and conflict at the end of Dutch colonial government at the beginning of the revolution for independence and Indonesia.

One of the interesting issues at the end of Dutch colonial rule is why there is a resistance movement against colonial rule and spirit of Indonesian nationalism appears so strong? In the conflict between society narrowing. Besides representing the Dutch East Indies colonial subjects with multi-ethnic state as the representation of the colonial Dutch, as well as the development of the Diaspora all over the complexity and the networks built between social and ethnic groups. This process goes hand in hand with the development of transportation (land and sea), communications, commerce, education, identity formation and transforms, information (newspapers, magazines) which, in turn, also encourages the development of the Diaspora. In addition, the influx of new ideas of nationalism, socialism, and Pan-Islamism is also sharpen the conflict. Phenomenon that one might encourage the development of Indonesian nationalism that was originally spearheaded by intellectuals and various forms of resistance against Dutch colonial rule in bulk and get a taste of blooming Indonesianess (Legge, 2010: 3338 and Wertheim, 1959: 44-51).

Although the people of Indonesia suffered severe physical suffering during the Japanese occupation, but the meaning seems to be developing a sense of Indonesian's growing well. Once again the people of Indonesia have the same general experiences as subjects of the Japanese occupation of the militarist government is very cruel. However, in the midst of cruelty, J apan instill the spirit of patriotism and nationalism in a way to build a spirit of anti-Western ways have 
to be ready commit war if the Western powers to invade their territory. Various preparations for war are made to conduct war games in large numbers that have not been carried out by the Dutch colonial government, set up a semi-military organizations like PETA (Defenders of the Homeland) and the mass organizations and youth are given exercises such as military discipline Seinendan, Keibodan, Fujinkai, and so on. In addition, the promises of the Japanese occupation government to give liberty to the people of Indonesia have been expected on the establishment of the independent Indonesian state. Symbols and fittings have also been prepared as a song, flag, language, constitution, and so forth to sow a sense of Indonesia's remarkable. In the days of J apanese occupation, population mobility also occurred in relation to implementation of the policies of the Pacific War. Many youths are sent to outside areas for the benefit of J apanese soldiers and mobilization Romusha like Heiho (Benda, 1983).

Furthermore, during the post-independence Diaspora and migration occurs more intensively. Various groups of status, social freedom, ethnic, and racial mobility do more fatherly than one region to another. There are many channels of Diaspora and migration that developed during the post-independence such as transmigration, military and government, education, mobility of labor, business, and so on. Apart from the effects of conflict arising from the phenomenon of migration and Diaspora during the post-independence period, but it is clear that the Diaspora and the internal migration is still a potential medium for crosscultural communication process, which is one basis for growth and development of the spirit of Indonesia's and complexity of political relations and power grows.

The second part of this research will contain a review of several case studies of Diaspora and migration phenomena in various places in Indonesia, such as the Diaspora in the southeastern island of Bugis and Makassar, the peoplein Sumatra, J ava, Banjar in Pantura, People Sampit Madurese, the Balinese in Lombok, and so on. In addition this section also includes several case studies on the existence of racial groups that have become community history and become an integral part in the process of forming such Indonesians of Koja, Arab, Indian, and so on.

\section{Conclusion}

Over the last two decades of Indonesian society underwent major changes that occurred after the monetary crisis since 1997. The monetary crisis which followed the general economic crisis followed by various crises such as the political crisis, a crisis of culture, and a crisis of confidence in a leader. Major changes in all areas eventually followed by a change of mind and perception of Indonesia's own community to community, nation and state. In the relationship that the passages back through the process of rewriting history about the formation and development of Indonesia's spirit needs to be studied again. This is related to the fact that the emergence of new challenges after the social changes so profound that require a step change in understanding of deciding the past and present and 
future. If history is not able to provide a way out of fatherly understanding of contemporary historical perspective of the history of science will be left by people because considered incapable of contributing to solving actual problems and not considered to have contributed in achieving a better future. Should be recalled that every true history is contemporary history.

One very significant factor for the emergence of the threat of disintegration which is and will be faced by the NKRI is the fading sense of history (historical consciousness) in the context of generational change. Therefore the influence of the wave of globalization and internal pressures arising from the "localization" of consciousness as a part of society with destruction of a nation. The main problem faced only seen in the present context without the return of its historical roots. The impact is that they are easier to sacrifice living together who have been nurtured for so long to achieve political and economic interests of the primordial and local. Although often strap socio-cultural relations between one group with another groupalso frequently felled by thesword and politics on behalf of thegods economy. But even sisal and communication culture that is more likely to understand each other's feelings and awakening consciousness are embedded together as a community of nations. The Phenomenon of cross-cultural communications that has significant role in the formation of Indonesian. In a relationship that Diaspora studies as a medium of cross-cultural communication in the process of formation of Indonesian spirit needs to be done in the framework of evocative memory back together as a community of nations. 


\section{REFERENCES}

Andaya, L.Y. (1995). The Bugis-Makassar Diasporas , J ournal of the Malaysian Branch of the Royal Asiatic Society; vol. 68

Anderson, B. (1983). Imagined community: Reflections on the Origin and Spread of Nationalism. London: Verso

Antara. (2011) . "MPR : Perlu Badan Khusus Pemasyarakatan Empat Pilar", (Online in:http:www.antaranews.com/berita/ 255378/mpr--perlubadan-khusus-pemasyarakatan-empat-pilar (Visited on $12 \mathrm{~J} \mathrm{une,} \mathrm{2011).}$

Arakaki, R.K. (2002). Theorizing on the Okinawan Diaspora , in: Ronald Y. Nakasone (ed.), Okinawan Diaspora. Honolulu: University of Hawai Press.

Benda, H.J . (1983). The Crescent and the Rising sun: Indonesian Islam under the J apanese Occupation 1942-1945. Providence: Foris.

Brown, M.E. (1993). Ethnic Conflict and International Security (Princeton: Princeton University Press.

Chang, W. (2010). "Kontrak social telah Berlalu? ,in: h t t p : / / w w w . unisosdem.org/ ekopol_detail.php?aid=8852\&coid=3\&caid=31 (Visited on 16 October, 2010).

Carlton J .H. Hayes. (1955). The Historical Evolution of Modern Nationalism (New York: Macmillan.

Cummings, W. (1998). TheMelaka Malay Diaspora in Makassar, c. 1500-1669 ， J ournal of the Malaysian Branch of the Royal Asiatic Society, vol. 71

Curtin, P.D. (1984). Cross-Cultural Trade in the World History (Cambridge: Cambridge University Press.

Cribb, R.(2000). Historical Atlas of Indonesia. Honolulu: University of Hawaii Press.

Drake, C. (1981). The spatial pattern of national integration in Indonesia. Transaction Institute of British Geographers (New Series)

Drake, C.(1989). National integration in Indonesia: Patterns and Policies. Honolulu: University of Hawaii Press.

Elson, R.E. (2009). The Idea of Indonesia: Sejarah Pemikiran dan Gagasan (translation of Zia Ansor). J akarta: Serambi, 2009.

Fabre, G\&Benesch, K. (2006). “Introduction, TheConcept of African Diaspora(s): A Critical Reassessment", In Genevieve Fabre \& Klaus Benesch (eds), African Diasporas in the New and Old World: Consciousness and Imagination (Amsterdam-New York: Rodopi. 
Fitzgerald, C.P. (1965). The Third China : the Chinese Communities in SouthEast Asia. Whitcombe and Tombs.

Frank, A.G. (1998). Reorient: Global Economy in the Asian Age. Berkeley-Los Angeles-London: University of California Press.

Gilroy, P. (1993). The Black Atlantic: Modernity and Double Consciousness. Cambridge Massachusetts: Harvard University Press.

Graaf, et al, (2004). Chinese Muslims in Java, XV and XVI century: Between historicity and Myth (New York: Tiara Discourse.

Gungwu , W. (1978). The Chinese Minority in Southeast Asia. Chopman Enterprices.

Hall, K.R. (1985). Maritimetradeand state development in early Southeast Asia. Honolulu: University of Hawaii Press.

Henley, D. (1996). Nationalismand Regionalismina Colonial Context: Minahasa in the Dutch East Indies. Leiden: KITLV Press.

Houben, V.J .H. (2002). "J ava in the 19th Century: Consolidation of A Territorial State , in: Howard Dick, The Emergence of A National Economy: An Economic History of Indonesia, 1800-2000. Leiden: KITLV Press.

Khattab, U.M. (2010). “Who Diaspora in Malaysia? The Discourse Ethnicity and Malay (Sian) Identity", Sosiohumanika.

Legge, J .D. (2010). Intellectuals and Nationalism in Indonesia: A Study of the Following Recruited by Sutan Sjahrir in Occupied J akarta. J akarta-Kuala Lumpur: Equinox.

Mangunsumbogo (ed). (1958). Fakta dan Dokumen-dokumen Untuk Menyusun BukuIndonesia Memasuki Gelanggang Internasional": Period IV: 1950-1955. J akarta: Ministry of Foreign Affairs of the Republic of Indonesia.

Manning, P. (2003). The African Diaspora: A History through Culture (New York: Colombia University Press.

Nagtegaal, S.L. (1996). Riding the Dutch Tiger: The Dutch East Indies Company and the Northeast Coast of J ava 1680-1743. Leiden: KITLV Press.

Paeni, M. (2008). Diaspora Bugis-Makassar dan Kebangkitan Nasional (J akarta: Ministry of Culture and Tourism.

Purcell, V. (1951). The Chinese in Southeast Asia. Oxford: Oxford University Press.

Ricklefs, M.C. (1983). A History of Modern Indonesia since ca. 1300. London: Macmillan.

Soekarno. (1965). An Autobiography as Told to Cindy Adams. Indianapolis: Bobbs-Merrill, 
Sulistiyono, S.T. (2007). "Oaring between Two Reefs: Globalization and the Dilema of the Reformation of Higher Education in Indonesia", this working paper was presented in the International Symposium on the Cultural Changes in Asia at Tokyo University

Sulistiyono, S.T. (2008). Sejarah Maritim Nusantara: Perkembangan dan Prospeknya, The working paper was presented in Seminar of Maritime Archeology held by History Education major, Teachingand Education Faculty, Lambungmangkurat University.

van Leur, J.C. (1983). Indonesian trade and society: Essays in Asian social and economic History. Dordrecht/ Providence: Foris.

van Miert, H. (2004). Dengan Semangat Berkobar: Nasionalisme dan Gerakan Pemuda di Indonesia, 1918-1930 (translation of Sudewo Satiman)/ J akarta: KITLV-Hasta Mitra-Pustaka Utan Kayu.

van 't Veer, P. (1977). Dutch War in Aceh (Translation Aboebakar). Banda Aceh: Ministry of Education and Special areas of Aceh.

Viekke, B.H.M. (2008). Nusantara: Sejarah Indonesia (translation of Samsudin Berlian). J akarta: KPG.

Wertheim, W.F. (1959). Indonesian Society in Transition. The Hague/ Bandung: Van Hoeve.

Widodo, J. (2004). Boat and the City: Diapora China's Coastal Cities and Architecture of Southeast Asia. Singapore: Marshall Cavendish Academic.

Widjojo, M. (2009). Rebellion Prince Nuku: Cross-cultural Alliance-Making in the Moluccas, c 1780-1810. Leiden-Boston: Brill. 
SINGGIH TRI SULISTIYONO

Diaspora and Formation Process of Indonesianess: Introduction to Discussion 